\title{
Los territorios de la violencia en la novela policial y la narcoliteratura latinoamericana: Mario Mendoza, Peter Elmore y Alejandro Páez ${ }^{1}$
}

\section{Territories of Violence in Detective Novels and Narco- Literature in Latin America: Mario Mendoza, Peter Elmore and Alejandro Páez}

\section{Danilo Santos López}

Facultad de Letras, Pontificia Universidad Católica de Chile. Santiago, Chile. dsantos@uc.cl

\section{Resumen}

El artículo expone la problemática de la violencia en las sociedades latinoamericanas a través de su representación en una serie de novelas publicadas a partir de los años noventa. Para ello se seleccionó las novelas policiales Enigma de los cuerpos (1995) de Peter Elmore, Satanás (2002) de Mario Mendoza y las narconovelas Corazón de Kaláshnikov (2009), El reino de las moscas (2012) y Música para perros (2013) de Alejandro Páez Varela. Ellos son textos que recogen la situación de los personajes-víctimas de la novela criminalizada a través de la mirada narrativa sobre territorios muy delimitados como la Lima de Elmore, la Bogotá de Mendoza y Ciudad Juárez de Páez Varela.

Palabras clave: territorio, violencia, novelas policiales, narcoliteratura, personajes víctimas.

\section{Abstract}

This article exposes the problem of violence in Latin American societies through the representation found in a series of novels first published in the 90s. The analysis focused on two detective novels: Enigma de los cuerpos (1995) by Peter Elmore, Satanás (2002) by Mario Mendoza and three narco-novels: Corazón de Kaláshnikov (2009), El reino de las moscas (2012) and Música para perros (2013) by Alejandro Páez Varela. These texts consider the situation of the protagonists-victims of the criminalized novel through a narrative perspective regarding limited, clearly-defined territories, such as Lima in Peter Elmore’s novel, Bogotá in Mario Mendoza’s and Ciudad Juárez in Páez Varela’s.

Keywords: Territory, Violence, Detective novels, Narcoliterature, Protagonists-Victims

1 Este trabajo forma parte del Proyecto de Investigación Fondecyt Regular $2015 \mathrm{~N}^{\circ} 1150484$ "Narcoestética: apropiaciones de un modelo cultural méxico-colombiano para la constitución de un nuevo formato literario y audiovisual en Chile" que dirijo como investigador responsable. 


\section{Introducción}

El artículo expone la problemática de la violencia en las sociedades latinoamericanas a través de su representación en una serie de novelas publicadas a partir de los años noventa y que refieren el desastre nacional a partir de la delimitación de una geografía específica. Para ello se seleccionó las novelas Enigma de los cuerpos (1995) de Peter Elmore, Satanás (2002) de Mario Mendoza y Corazón de Kaláshnikov (2009), El reino de las moscas (2012) y Música para perros (2013) de Alejandro Páez Varela como textos que recogen la situación de los personajes-víctimas a través del formato de la novela criminal. Inicialmente se plantea la descripción del personaje como víctima de una situación concreta de agresión para demostrar posteriormente las conexiones con razones que pueden vincular este tipo de violencia con la propia participación del Estado. Se conjuga un período específico desde mediados de los años noventa hasta el presente para desarrollar en las sociedades presentes referidas en los textos la situación de una violencia muy concreta que afecta a los personajes que son víctimas y victimarios en acontecimientos que parecen no tener salida en su circularidad argumental, es decir, el ciclo de violencia en que tales personajes están atrapados. A la vez, involucran la participación indirecta del Estado en la resolución conflictiva de tales historias, especialmente en las geografías muy delimitadas mostradas como la Lima de Elmore, la Bogotá de Mendoza y de modo parcial a través de la particular violencia que sacude a Ciudad Juárez de Páez Varela. Cuando aludo a geografías de la muerte me inspiro en el concepto de espacios de la muerte desarrollado por Aquille Mbembe para referirse a las colonias como espacios de la necropolítica ${ }^{2}$. Los espacios de muerte designan aquellos lugares que han sido ocupados por el poder soberano o por quien ejerce el poder para para segregar y provocar la muerte. A mi modo de ver respecto a los tres lugares que se presentarán, es el tercer caso, el de Ciudad Juárez y los lugares concomitantes como el poblado de Zaragoza en México los que más se aproximan a este carácter de excepcionalidad en que los personajes son victimizados. Sin embargo, para la joven María en su calidad de mujer desplazada en Bogotá también se puede considerar en aquella situación así como para los indigentes y en el caso peruano, de modo más indirecto, el ejercicio de violencia recaerá en aquellos testigos iniciales de los cuerpos dispersados en Lima.

Para hablar de territorio se acude al geógrafo cultural brasileño Rogerio Haesbaert, que postula unas útiles observaciones conceptuales. En su texto "Viviendo en el límite: los dilemas del hibridismo y la multi/transterritorialidad" propone un acercamiento al territorio que proviene de la movilidad contemporánea y que depende de la definición de poder:

2 Mbembe se inspira en la lectura espacial de la ocupación colonial de Frantz Fanon que habla de una "ciudad del colonizado" para dar cuenta de un espacio en que se puede morir arbitrariamente en cualquier parte y por cualquier mano (Mbembe 45). 


\begin{abstract}
Es importante aquí, presentar, aunque de forma muy sucinta, las distintas caras de la multiterritorialidad. Partimos de un concepto menos parcelario del territorio; no lo definimos simplemente por un recorte empírico, una "porción de lo real", sino por una problemática y una forma de abordarla, o sea, por una determinada "mirada" y, a partir de aquí, al poner la atención sobre un aspecto de la realidad, defendemos que el territorio es el espacio geográfico visto a partir de "poner el foco" en las relaciones de poder, sea el poder en sus efectos más estrictamente materiales, de carácter político-económico, sea en su articulación más simbólica. De esta manera, se busca abordar el territorio a través de las relaciones de poder que le son inherentes: desde un poder más "tradicional", de naturaleza estataladministrativa, hasta su configuración más simbólica, donde la propia construcción identitaria es vista, antes que nada, como un instrumento de poder (o, para utilizar un término polémico, de "empoderamiento") de los grupos y/o clases sociales (61).
\end{abstract}

Para ello, Haesbaert distingue entre espacio y territorio, al que asocia vinculado con relaciones de poder y va a ser el poder el que defina el territorio y sus modificaciones, por supuesto aquí la deuda del investigador es con Michel Foucault. Y el poder foucaultiano no es un poder centralizado sino múltiple lo que lo lleva a hablar de una "concepción multiescalar del territorio" (Haesbaert, "Del mito de la desterritorialización" 26), es decir, de varias escalas y en el que hay macro y microterritorios. Para Haesbaert el territorio tiene una base material de origen pero también una importante dimensión simbólica. El autor califica al espacio como un proceso en uno de cuyos ejes estaría un "territorio puramente funcional, y en el otro un territorio puramente simbólico" (27). Aunque el geógrafo defiende la base material original del territorio, conceptualiza a la territorialidad como un campo de representaciones territoriales que excede al territorio y que puede estudiarse de un modo puramente simbólico. Esto funciona para el ejemplo del migrante que se proporciona (28) y que a partir de un territorio de base puede circular por diferentes territorialidades en lo que Haesbaert denomina una concepción multiterritorial del mundo. Este proceso lo entiende como "la posibilidad de tener la experiencia simultánea y/o sucesiva de diferentes territorios, reconstruyendo constantemente el propio" (34-5).

\title{
Tres versiones latinoamericanas de la ficcionalización territorial de las víctimas
}

Satanás, de Mario Mendoza: la versión bogotana del desastre

Satanás presenta una reflexión ética sobre el mal contemporáneo, referido esto en el desarrollo argumental que tiene como trasfondo una Bogotá ominosa, poblada de desigualdades y fracturas sociales y en que todos los personajes son víctimas, aún el 
asesino que es el personaje eje de la construcción novelesca. Esta identificación de la ciudad con una idea del mal contemporáneo se aprecia en las reflexiones del sacerdote Ernesto, personaje bisagra ${ }^{3}$ del relato y en el que convergen todas las historias, sólo en apariencia, paralelas y desconectadas:

El triunfo del mal. ¿Por qué no? ¿No bastaba una caminata por la ciudad para darse cuenta de que estaba deambulando por entre círculos infernales? ¿ No eran los rostros de los mendigos, de los locos, de los solitarios, de los prisioneros, de los suicidas, de los asesinos, de los terroristas, de los hambrientos, testimonios abiertos del reino de las sombras? Recinto de desgracia y de miseria. Sí, así era, sin duda (203).

La novela se inicia con la referencia indefinida a un mercado o feria anónimo y termina con otra alusión, en este caso definida e histórica, a la matanza ocurrida en el restaurante italiano de Bogotá "Pozzetto" en 1986. Allí, el ex combatiente de Vietnam Campo Elías Delgado, lector de Stevenson, masacró a cerca de treinta personas ${ }^{4}$. Más allá de esta sombra maligna ${ }^{5}$, la novela se articula en torno a tres personajes: el sacerdote en crisis de fe Ernesto, el pintor Andrés y la joven migrante María, que pasa de vendedora ambulante en una feria a seductora de ejecutivos y yuppies de la Zona Rosa de Bogotá.

La novela expone una polémica ideológica que traduce el malestar y la maldad de la división social a través de la exclusión territorial: el Norte y la Zona Rosa asociada al triunfo económico y al esparcimiento de las clases privilegiadas de Colombia; el Sur como lugar sin simbolización posible y el centro como el lugar de la crisis y la posibilidad del cambio y la dinámica a través de la peregrinación de los personajes, de Plaza Bolívar y de las iglesias de La Candelaria. Se observa en la disposición espacial de Mendoza una gran variedad de territorios por los que circulan los personajes y heterogeneidad social para el acceso a ellos, más alá de que Mendoza configure literariamente el centro histórico de Bogotá como el locus de su narrativa.

En la construcción de actores o de sujetos urbanos, la novela presenta una serie de sujetos anónimos y otros identificables, que o bien son los protagonistas del relato: Ernesto, Andrés y María; o bien, juegan un rol determinante en el argumento de la misma como el ex soldado Campo Elías Delgado. En el primer caso: los sujetos con nombre expresan una crisis que corresponde a las distintas tramas paralelas del relato,

3 Utilizo el término bisagra según el concepto de Prado Biezma (1984) en Cómo se analiza una novela que alude al cruce de una acción a otra. Yo modifico esta concepción y la amplío a personajes que sirven para catalizar los acontecimientos narrativos y que marcan pautas de modificación en las acciones (289).

4 Son veintiocho personas las que Campo Elías Delgado habría masacrado en total según la investigación de Olaya Molina en Pozzetto. Tras las huellas de Campo Elías Delgado (128-31).

5 En que El extraño caso de Dr. Jekill y Mr. Hyde es el libro de cabecera de Campo Elías lo que provoca a mi entender que la duplicación novelesca de Stevenson se proyecte en el personaje de una niña poseída que yace en La Candelaria y que no solo sobreviva al asesino sino que se reúna con los desposeídos de la ciudad. El "Soy legión" reinterpretado por Mendoza respecto a los indigentes y sujetos anónimos que deambulan por Bogotá. 
las crisis personales de Andrés y María anudadas en su conocimiento fraternal del sacerdote Ernesto. En el otro, la historia de Campo Elías, como el detonante que en las sombras planea su peculiar acto de exterminio. Esta última historia se presenta como la del desarraigo paradigmático respecto a la ciudad, Campo Elías, aunque se desempeña como un profesor de inglés está marcado por su participación como soldado-asesino en la guerra de Vietnam y no hay ningún lazo que lo ate con Bogotá, lo que está representado con la brutal comunicación que tiene con su madre. Su única comunicación real y los mensajes provienen de la literatura y de la división planteada por El extraño caso del Dr. Jekill y Mr. Hyde de Stevenson. Para el caso de este personaje referencial el territorio simbólico de Vietnam, su lectura de clásicos anglosajones y su calidad de profesor de inglés testimonian la división territorial en que el personaje va cayendo mentalmente absorto en su participación como mercenario en la guerra y como alguien que no tiene un territorio definido para definir su existencia particular, de hecho la matanza la cometerá en un restaurante de comida italiana.

En los otros tres casos, el desarraigo proviene de distintos ámbitos. Pero también hay que incluir la diferencia que se produce si los bogotanos son nacidos en la ciudad o provienen del exterior de la capital colombiana. En Ernesto, el hastío respecto a Bogotá se produce por el encierro religioso representado por las iglesias de La Candelaria y la represión sexual por un lado, así como la respuesta de la iglesia popular marxista que tampoco le satisface aunque es izquierdista, en las que no ve otra salida que abandonar el sacerdocio y reconocer como pareja a una joven empleada de la iglesia Irene, que de facto es su compañera de intimidad. La opción de Ernesto tiene que ver con la profunda incomodidad que siente al no poder ayudar a un asesino que se comunica infructuosamente con él antes de cometer sus homicidios y a la poseída de La Candelaria, quien lo seduce. El del pintor Andrés porque necesita salir de Bogotá y tomando como modelo de vida la huída de Gauguin a las tierras polinésicas, también planea escapar de la asfixia bogotana y de sus indecisiones sentimentales y del extraño carácter visionario que adquiere su arte, al modo de imitar un nuevo tipo de pacto fáustico con la destrucción de quien sea retratado. El desarraigo de la joven María es particularmente interesante. Ella es afuerina al ser una migrante que ha sobrevivido a la matanza de sus familiares en el pueblo de Miraflores del sur colombiano y que se encuentra de tránsito ya sea en el amenazador mercado en el que labora al inicio de la novela, como en la breve incursión de delincuente en los bares de la Zona Rosa que incluyen su violación. A la vez que división física del territorio bogotano que es explorada por Mendoza desde la oposición Norte-Sur, el escrito explora la dimensión simbólica de la religión como nexo polémico de cohesión nacional al interior de la ciudad. Como eje de aquello son las iglesias del centro histórico y una percepción que lleva a las alturas de la ciudad, el Monserrate y el departamento desde el que contempla la ciudad Andrés y que connotan una división entre la altura es decir lo espiritual y lo religioso (el Monserrate es un santuario tradicional) y la base material del espacio físico que es la propia ciudad de Bogotá. La versión religiosa de la 
constitución citadina está confrontada desde la materialidad sexual de los personajes que tiene una traducción muy literal cuando Ernesto como sacerdote se enfrenta a la niña poseída y siente un olor nauseabundo a alcantarillas (el centro material de la urbe) que precede al desafío hipersexualizado de aquella que lo hace abandonar avergonzado la habitación sumido en una erección incontrolable, que no por azar se encuentra ubicado en el barrio La Candelaria de la ciudad.

La serie de desplazamientos de los personajes muestran cómo se trata de cambiar de una situación planteada inicialmente de crisis a una situación de mejoría, ya que tales procesos implican a su vez dinámicas de movimiento territorial. Así, en el caso de Ernesto, abandonar la Iglesia que lo cobija pero que lo separa de los seres anónimos de la calle, para hacerse un ser cotidiano, un ser que se va a relacionar directamente con el mundo de los marginados respecto a la empleada con la que mantiene relaciones. Andrés se muestra agobiado e imagina la posibilidad de una huída de la asfixia burguesa en la que se ve inmerso y esto también lo lleva a la desaforada incursión sexual con su ex novia a pesar de tener conciencia que es portadora del SIDA. En este caso, también los territorios se mezclan con las incursiones privadas y establecen una convergencia en la que la intimidad prohibida, aparece como la territorialización erótica. En el sentido de Haesbaert, en su texto "Del mito de la desterritorialización a la multiterritorialidad", de ocupar un territorio que es distinto al habitual en que circulan los personajes pero que en la novela se mezcla eróticamente con el cuerpo físico de la amada que traduce la huída del territorio que asfixia a los personajes: el sacerdote con Irene, Andrés con su novia Angélica y María con una joven vecina, que la acoge como si fuera su hermana extraviada. En este caso, Iglesia, motel y departamento sirven para ilustrar las salidas de cada uno de los personajes. En este sentido, con Haesbaert, si bien los personajes aparecen asfixiados en los lugares de Bogotá y también simbólicamente por las restricciones religiosas y políticas del desastre nacional según Mendoza, la posibilidad de salida tiene que ver con una nueva búsqueda de territorios. Aquí con el peso de lo simbólico-físico, por ejemplo para Andrés que tiene un sueño de huida a lo Gauguin (que vemos como contraparte del Vietnam de Campo Elías), los personajes quieren afrontar nuevas apropiaciones en sus opcionales personales para abandonar el Bogotá simbólico que funciona como espacio de clausura. Que por supuesto es desigual en las posibilidades que tienen Ernesto y Andrés respecto a una mujer migrante como María, en que los primeros son sacerdote y artista frente a una joven que en un momento opta por la delincuencia como alternativa de ejercicio de territorio diferente a su condición de vendedora ambulante (y que le permite modificar amoralmente su definición física de territorio).

Hay otro tipo de personajes, ligeramente secundarios, que constituyen parte de las voces que se oyen en Bogotá: Los indigentes que, en Satanás establecen una conexión con Scorpio City, la narrativa anterior de Mendoza, que tenía como objeto a los sujetos urbanos anónimos que funcionan como los residuos de la sociedad. Así, aquí reaparece 
este conjunto humano transformado en una serie de pobladores marginales: prostitutas, recicladores de basura, albañiles, vendedores de droga, trabajadores, indigentes y vagabundos. En el artículo "Territórios, in-seguranca e risco em tempos de contencão territorial", Haesbaert acuña el concepto de contención territorial para referirse a la creación de barreras que redireccionan la circulación de los sujetos y que actúan como nuevas fronteras territoriales. En Mendoza se articula en la novela anterior esta segregación de los personajes anónimos, mientras que en el texto actual se podría interpretar que funciona como una respuesta de los sujetos anónimos desde la perspectiva de un ángel vengador como Campo Elías a esas fronteras simbólicas que terminan confinando a los sujetos anónimos a la zona Sur y como nómades al Centro Histórico de la ciudad.

En este caso, los trayectos de los tres personajes, especialmente en el caso del personaje Andrés, aunque también en el del sacerdote Ernesto que fracasa en la comunicación con sus feligreses muestra ese mundo invisible de una ciudad que subsiste con cerca de ocho millones de habitantes:

El cielo se oscurece y al fondo, por encima de los almacenes y las compraventas de la Carrera Décima, unas nubes rojizas y púrpuras son las últimas huellas de unos rayos de luz que se difuminan en el occidente. Varias prostitutas humildes y mal vestidas abordan a los caminantes que las observan con curiosidad. Los recicladores de basura empujan sus carros de madera y de vez en cuando tienden la mano y piden una limosna a las personas que esperan un bus o una buseta para regresar a sus casas. Andrés camina entre la multitud como si estuviera en otra dimensión, ajeno al ruido y al trajín de la calle (184-5).

Andrés en su larga caminata reflexiva se encuentra con una serie de habitantes, que son asimilados en la novela a desechos, ya que están ocultos y son estigmatizados y excretados por el mundo globalizado. Aquí los llamados no-lugares ${ }^{6}$ de la globalización desaparecen y somos testigos de la llegada a un bar marginal en donde se encuentran prostitutas y trabajadores anónimos. Aunque también se halla con el ángel exterminador de los desplazados, con Campo Elías Delgado que los igualará en su demencial exterminio. En relación a los residuos sociales, la secuencia final de la novela, tras los crímenes del restaurante Pozzetto, relata los asesinatos cometidos por la poseída y su desaparición entre los sujetos anónimos de la ciudad:

La policía no había podido dar con ella y los periodistas suponían que seguramente estaría vagando de calle en calle, confundida entre la multitud de indigentes y alucinados que recorren la ciudad durante horas interminables y que suelen pernoctar en potreros baldíos, en caserones abandonados, en parques poco concurridos o debajo de los puentes en guaridas improvisadas y malolientes (283).

6 Por no-lugares sigo la conceptualización discutible pero útil de Marc Auge con la que reconoce a aquellos espacios de transitoriedad en que los sujetos circulan de un modo funcional y sin establecer vínculos de pertenencia ni de identidad como los aeropuertos y los supermercados. 
Esta asimilación final de la niña poseída de La Candelaria con los indigentes nos muestra cómo el discurso público termina el relato del desastre, "se perdió entre los vagabundos"; pero, sobre todo, nos recuerda y pone en alerta sobre los personajes marginados-victimizados de la sociedad. De hecho, se asimilan nuevos espacios, las calles como lugar de residencia de "indigentes y alucinados" y los sitios en donde duermen "potreros baldíos, caserones abandonados, parques ocultos y debajo de los puentes" en una especie de refugio caracterizado por la "improvisación" y el "mal olor". Para una lectura territorial de esta segregación es sumamente explícito que al inicio del texto la acción se concentre en el mercado popular y que la novela termine con una relación de los habitantes nocturnos de la gran ciudad, que no tienen otro hogar que un sitio miserable para pernoctar. Lo que lleva a reflexionar que gran parte de la orquestación novelesca sirve para dar cuenta que esta masa anónima capitalina reinterpreta la asfixia de los personajes centrales del texto que mueren para que la multitud anónima persista en la ciudad a través de sus desplazamientos múltiples y sus practicas territoriales múltiples superen estas barreras simbólicomateriales de segregación o contención territorial como lo denomina Haesbaert ("Territórios, in-segurança”).

En este caso, parece comprobarse que la textualidad novelesca de Satanás se plantea en su inicio con una plaza de mercado y en su desenlace con las calles y los lugares abandonados, al definir un modo textual de entrar a la novela que es también un ingreso y un cierre espacial. O, de otro modo, un texto-ciudad o texto-novela ${ }^{7}$ que tiene su origen referencial en territorio como la matanza del restaurante Pozzetto. Lugar que solo cobra sentido en la resolución de este desastre porque también es un texto-ciudad porque si uno reconstruyera con tres dimensiones la novela seguramente nos observaríamos caminando en ella y mirándola como lo hace el personaje de Andrés desde el Monserrate. Básica en todo caso y más allá de esta disposición semiótica del territorio textual, es la aparición de estos personajes anónimos que actúan como comparsas de los protagonistas de la novela. Así como Ernesto es el personaje de convergencia de los otros dos protagonistas, finalmente, Campo Elías Delgado es también el personaje bisagra ${ }^{8}$ que produce la reunión de los personajes y define el desenlace ya que motiva los acontecimiento en un sentido diferente al que como lectores habíamos definido respecto a las posibilidades y nuevas expectativas que los tres personajes habían planteado en la novela, es decir, lograr salir de la asfixia ideológica de la ciudad (política, material-económica, religiosa). De hecho, cuando asesina a su alumna de inglés y a la madre de esta, les restriega por vivir en otro mundo,

7 Con texto-ciudad o texto-novela me refiero a la conceptualización con la que Italo Calvino interpreta el esfuerzo de Balzac de transformar una novela en una metrópolis en Por qué leer los clásicos (112). Yo lo amplifico semióticamente al proceso de configuración de la novela de Mendoza que se articula territorialmente desde el Centro Histórico bogotano y con una lectura de los sujetos anónimos que la recorren.

8 Ya que no sólo origina la novela extratextualmente al ser referencialmente el núcleo sobre el que Mendoza concentra el inicio de la acción. 
no en el mundo del sufrimiento que él se va a encargar de que conozcan. En el caso de Campo Elías y de la situación de desenlace en el Pozzetto, lo observamos cruzar varios espacios hasta llegar a este lugar de reunión y de esparcimiento y apurar el asesinato masivo. En este sentido, el local constituye el centro de cierto universo cosmopolita que en la lectura metafísica de la novela necesita ser conjurado por este nuevo "ángel exterminador" y que social e ideológicamente muestra un desastre en el mundo globalizado, en el mundo de la asepsia, las manchas de sangre con que Campo Elías destruye el imaginario burgués del encuentro social nocturno. Para que se produzca el cierre semiótico del libro, Mendoza invoca el restaurante Pozzetto como territorio referencial de la masacre y a la vez punto de convergencia de todos los personajes de la novela en un lugar vinculado a una zona privilegiada económicamente de la ciudad y con una posible atribución como local italiano a un no-lugar si lo cotejamos con otros sitios criollos de alimentación. Haesbaert ("Del mito de la desterritorialización”) cita preferentemente a Robert Sack en su definición política de territorio como un espacio al que se puede controlar el acceso, Pozzetto cumple desde la lógica del capital el acceso diferenciado a este lugar y es aquí en donde se produce la masacre de una multitud. Aunque el suceso es absolutamente referencial, para comprender la lógica novelesca funciona de modo coherente en esta confrontación multiterritorial que presenta la novela en su conjunto. Y en la interpretación que plantea la novela se resuelve de manera sangrienta, por ejemplo, las brechas entre la Zona Norte, la Zona centro y el resto residual de Bogotá, en un acto de cruenta comunicación con la sociedad colombiana. De hecho, la acción de Campo Elías es muy cercana en el tiempo a la toma del Palacio de Justicia por el M-19 y la masacre que ocurrió en este edificio nacional debido al operativo militar indiscriminado que provocó el incendio de la institución y que hasta el día de hoy origina respuestas disímiles en la atribución de responsabilidad debida al mismo procedimiento ordenado desde el ejecutivo, al propio M-19 e incluso a Pablo Escobar'. Se puede pensar en una suerte de reflejo especular de la matanza o distorsión de las masacres que afligen a la conciencia nacional. Y que el propio Mendoza tiene presente cuando el personaje Andrés reflexiona desde la perspectiva de un desastre nacional a la incapacidad del Estado y de la nación para impedir la serie de masacres y muertes que son recurrentes en la historia del país.

Así, Mendoza mostraría a Bogotá asfixiada por represiones institucionales, matanzas, insurrecciones que actúan como reflejo del malestar metafísico que enhebra la novela como un tejido en descomposición. Esto se muestra especialmente a través del deterioro de Bogotá en La Candelaria y en el centro histórico mostrado por los olores, la lluvia y la humedad repugnante con la que se confronta particularmente Ernesto cuando recorre la ciudad que es una posibilidad de lectura del Centro que

9 Para tener un balance reciente sobre responsabilidades y las críticas que se han hecho de este operativo que sigue envuelto en el misterio por las responsabilidades del ejecutivo respecto al brutal procedimiento, ver Adolfo Atehortúa, "Decisiones y narcos. Discusiones recientes en torno a los hechos del palacio de justicia" (2011). 
incorpora la idea de la decadencia social e ideológica de la sociedad bogotana. Esto se comprende desde una concepción del territorio como poder involucrado en las nociones inspiradas en Foucault de Haesbaert y que ayudan a entender una suerte de respuesta simbólica imaginada de Mendoza a las iniquidades de la situación nacional. Para ello, el escritor produce una interpretación paradojal de la "entropía social" 10 de Colombia a través del peso de la tradición colonial de la religiosidad, que espacialmente se identifica con las Iglesias y La Catedral enclavadas en el barrio colonial de Bogotá. Esto con el fin de mostrar los cimientos del malestar ideológico convertido en angustia metafísica y material, identificada con elementos del imaginario sacro, por ejemplo: María es casta, prostituta y asesina, el sacerdote Ernesto es izquierdista y busca recuperar su fe y el artista Andrés es fáustico y visionario a la vez. Todos conforman un peculiar triángulo sacro/profano que se destruirá por la intervención simbólica del mal que en la novela se muestra en la representación de la maldad satánica que es expuesta casi desde el inicio de la novela en la figura duplicada de la muchacha poseída de La Candelaria y del ángel exterminador del Apocalipsis vietnamita. Esto en un nivel individual de crisis, que es la traducción de la escisión material de Bogotá en Norte/Centro/Residuo. Lo que no hace escatimar que la otra cara de esta crisis es la situación concreta de los actores sociales anónimos que se ven condenados al desplazamiento continuo respecto de los sujetos que detentan el poder invisible y que son mostrados parcialmente a través de los despreocupados yuppies que se divierten en los bares de la Zona Rosa.

\section{La víctima fujimorista de la violencia estatal: descuartizados en Lima}

Enigma de los cuerpos de Peter Elmore es una novela peruana que da cuenta de los excesos de la violencia estatal. En el relato la ciudad ocupará un lugar destacado como articuladora de los asesinatos ya que los crímenes no sólo acaecen en la metrópolis, sino que aquella precipita estos acontecimientos con una participación activa en la configuración de la maquinaria de corrupción estatal que se muestra allí. El territorio de Lima es un espacio de poder como señalaría Haesbaert ("Viviendo en

10 Este concepto también se utiliza en Teoría de Sistemas (Cfr. "Introducción a los Conceptos Básicos de la Teoría General de Sistemas", Marcelo Arnold y Francisco Osorio, localizado en www.facso.uchile.cl/publicaciones/ moebio/03/frprinci), entendido como la descomposición de la estructura de un sistema, perdiéndose toda diferenciación de los elementos que lo componen, cuyo resultado es el desorden y el caos. Para efectos de esta lectura de los hechos referidos en la novela apunto a la desorganización social que el propio Mendoza explicita desde la concepción pesimista del personaje Andrés, quien habla de entropía en este sentido lato. Como tal es la lectura ideológica de los acontecimientos nacionales que constituirían la entropía como pueden ser los crímenes de Campo Elías Delgado, la masacre del Palacio de Justicia, el incendio del edificio de Avianca, Mendoza busca ligarlos a cierto peso del Estado y a la propia institución eclesial, de tanto peso en la organización de la sociedad colombiana. De ahí la paradoja, como institución sostiene la organización nacional pero tiene su culpa en que aquella institucionalización finalmente ha conducido a un fracaso nacional. 
el límite") y está marcado por múltiples cruces y territorialidades que involucran a los sujetos de desigual modo como se verá de manera radical en los efectos sobre los personajes. El protagonista, un periodista llamado Andrés Saldívar, trata de descifrar sucesos vinculados a una oscura trama de poder y de ligazones políticas que darán cuenta de una época conflictiva como es la década de los noventa en Perú. Entonces es justamente una mezcla de crónica roja y de articulación política lo que en verdad se mide en la novela a través de actores, asuntos y modos de escritura cercanos a la entrega periodística. Así, Andrés necesitará circular en las urbes como un detective y reconstruirá la ciudad del conflicto, traspasada por el factor político como modo de articulación del problema.

Los sucesos son presentados como crímenes horrendos y con explicaciones difusas desde el ámbito de los medios de comunicación lo que sobre el colectivo limeño produce miedo e inquietud. Un elemento a destacar en esta composición es la relación de esta irradiación periodística con la ficción documental, lo que acuña un verosímil ${ }^{11}$ híbrido como efecto de esta mezcla intergenérica entre los formatos del relato y los de la crónica roja. Se ve que el verosímil mencionado está articulado inicialmente por la descripción de los cadáveres y cómo son encontrados desmembrados y percibidos en/desde la ciudad por distintos barrios. Así, la novela establece una inicial relación a través del crimen y del hallazgo de los restos de descuartizamientos. Cuando Andrés Saldívar es enviado a cubrir el caso del descuartizado, se revela este carácter de la crónica roja amarillista en la presunción del personaje "Al principio había creído que no pasaba de ser un invento destinado a aumentar el tiraje, pero al parecer iba en serio. Una versión limeña de Jack. Venía botando pedazos de cadáveres desde enero, sin explicaciones" (Elmore 12). De hecho, a Andrés no le parece una buena idea hacerse cargo de seguir la pista del descuartizador, especialmente porque tendrá que entrevistar a un testigo en un territorio que no es el adecuado para él, ya que proviene de una familia de clase media alta y tiene que ir a zonas que materialmente no lo producen comodidad. Antes, él había establecido una relación falsa entre la versión limeña de Jack, como él la llama, y la venta de un producto masivo, en este caso, la prensa amarillista de la crónica roja:

Pistas nuevas llevarían a descuartizador

Quinto hallazgo fue pierna en granja

El día martes de la semana en curso, en una granja situada en el km. 33 de la Panamericana Norte, se encontraron restos de una nueva víctima del denominado Descuartizador de Año Nuevo. La identidad del occiso se desconoce, así como se ignora aún la de las cuatro víctimas anteriores del enigmático asesino.

11 Utilizo verosímil como régimen de lectura de un género. Es el tercer sentido en que Tzvetan Todorov comenta la relación del verosímil con el género y en que señala que llegan a confundirse. Así, cada género tiene su propio verosímil. 
Sin embargo, en la División de Homicidios de la Policía de Investigaciones trascendió que efectivos de ésta habrían obtenido valiosas pistas en la escena del crimen, las mismas que podrían conducir a una pronta solución del caso. De las dependencias de Homicidios emergió, en horas de la mañana del día de ayer, el propietario de la avícola "San Román", Gerardo Dupuy. Dupuy, que se negó a hacer declaraciones a la prensa, fue quien llamó a las autoridades luego de hallar la pierna de la víctima en una funda de guitarra (102).

Si bien el amarillismo aparentemente se exhibe en la descripción de los despojos y cómo aparecen envueltos, en verdad, el autor va a privilegiar el contacto directo y los efectos desastrosos que sobre la gente provoca este despertar ante la ciudad criminal. Utilizo este calificativo para referir el atributo de la urbe como engendradora de los crímenes que son efectos del descubrimiento del cuerpo desmembrado, es decir, las nuevas víctimas como Julián Poma y José Chamochumbi. Al respecto, Elmore subraya cierto elemento de cotidianeidad urbana en el trabajo de Asunta, de Julián y de José quienes se desempeñan como obreros y cuyo mundo se va a ver desarticulado por los miembros trozados. En parte la novela explica el fenómeno de los conflictos de los años noventa y de la guerra contra Sendero Luminoso y los ecos que llegan a Lima a través de los estados de shock en las que quedan los personajes comunes de la ciudad. Por lo que territorialmente los movimientos que la novela cubre establecen un diálogo Ayacucho-Lima que permite establecer una correcta interpretación de lo que había sucedido. El territorio permite establecer una dinámica que tiene como actores a Sendero Luminoso, al Ejército peruano y a infiltrados que resuelve el misterio criminal. En el desenlace, en realidad, en vez del asesino serial tenemos a las fuerzas de represión militar como autores del crimen. La ciudad aparece como un escenario de guerra, al duplicar la zona del conflicto armado y cuya imagen es configurada geopolíticamente por los militares al intervenir la cartografía la ciudad al dejar en distintas partes los restos de los descuartizados que provienen como víctimas de otra zona de Perú como es la de Ayacucho. Si bien los personajes investigadores tendrán que viajar a la sierra para finalmente descifrar un crimen que quedará en la absoluta impunidad, Saldívar (nos) descubre a las otras víctimas de la guerra, a esos seres anónimos que caen en la ciudad y que aparecen reconocidos como testigos, de este modo, Serna, Chamochambi y Poma son víctimas de la violencia que ejercen los medios indirectamente. En este sentido la capital también es configurada mediáticamente y como sede del Ejecutivo y de los poderes estatales tritura a aquellos que no pueden ni deben introducirse en lugares que tienen la contención territorial de Haesbaert ("Del mito de la desterritorialización"). Aunque en este sentido, son los restos humanos los que invaden el territorio de estos seres anónimos que justamente pierden tal calidad debido a que se transforman en testigos. Es esta calidad la que va a complementar la ansiedad que produce el mismo momento del descubrimiento de los cuerpos trucidados. 
Por otra parte, el texto es un reportaje que se encarga de describir morbosamente el tipo de ataque que han sufrido los cuerpos, aunque escamotea información esencial para comprender realmente las verdaderas motivaciones de las muertes. Frente a los efectos del cadáver como motivador de cambios en la dinámica del relato, también se produce en la novela de Elmore la proyección de los miedos y las pasiones que despierta el descubrimiento de los cadáveres sobre los afectados. En el caso de la revelación de las identidades de los testigos, Julián Poma el emolientero que encuentra parte del cuerpo en el centro de Lima escondía un secreto de su pasado delincuencial que va a precipitar su asesinato. En tal caso, Poma abandona el anonimato de las multitudes y a su vez va a ser descubierto como criminal y localizado por sus futuros victimarios:

[Julián Poma] Fue al voltear en la esquina de Malambito que chocó con un bulto grueso [...] Cuando lo quiso arrimar, se dio cuenta de que se trataba de una maleta. ¿Qué habría adentro? La arrastró hasta donde no estaba tan oscuro. Pesaba bastante. El cierre no cedía y notó que la lona estaba empapada de un líquido tibio y viscoso; insistió, de todos modos, picado por la curiosidad. De repente el contenido valía la pena. Forcejeó un rato, jadeando, hasta que corrió el cierre. "Ya está", dijo, y respiró triunfante. Quién sabía si, después de todo, estaba con suerte. Se agachó para retirar su botín, todavía sin poder discernirlo claramente. Al tocarlo, sin embargo, dio un respingo de asco.

Julián trastabilló hacia atrás, sin aire para gritar, sin poder quitar los ojos del bulto. No podía ser, no era posible. Durante un minuto de agonía sintió que el corazón le pateaba el pecho y que sus piernas no iban a responderle jamás. Por fin, se lanzó a correr despavorido hacia la plaza Unión.

Dentro de la maleta estaba, embutido, el tronco ensangrentado de un hombre (12).

Tanto Asunta Gálvez como José Chamochambi también sufren los efectos del miedo que obsesiona a las víctimas cuando son testigos accidentales de los crímenes urbanos. En ambos casos, también son actores periféricos que se ven afectados en su diaria actividad por la visión de los miembros cercenados que ellos encuentran desperdigados en distintos lugares de Lima. Asunta es una vendedora de víveres que descubre una pierna en Vitarte, distrito limeño de gran población y caracterizado por sus actividades comerciales, en camino de madrugada al mercado:

El hallazgo ocurrió mientras cruzaba un terral que en otros tiempos fue un potrero y ahora sirve como cancha de fútbol y cementerio de carrocerías [...] Desde esas fechas se había quedado medio tocada de los nervios; cualquier zoncera le ponía la carne de gallina y el corazón en la boca, a ella que siempre había sabido tener carácter fuerte. Más aún, la asaltaban seguido unos temblores de perro chino que no paraban ni con valeriana: sentía entonces como si en la médula misma de los huesos se le hubiese metido un frío blanco, recio (64-5). 
La aparición del cadáver mutilado en la ciudad modifica la existencia de todos los sujetos, aún los involucrados en forma indirecta y produce inquietud y ansiedad en la urbe capitalina. Llama la atención cómo el miedo organiza uno de los ejes de la relación de los personajes con la ciudad, miedo que por otros motivos va a experimentar el periodista con ínfulas de artista burgués Saldívar cuando viaje al territorio periférico de Poma. El temor urbano ante este crimen refleja el de las mutilaciones y atrocidades compartidas entre Sendero Luminoso y la represión militar en Ayacucho. Como tal, el miedo de los testigos es registrado en la bitácora policial y asimismo en la crónica periodística de los acontecimientos. La huida de Chamochambi del lugar del descubrimiento va a ser leída como culpabilidad por la policía y él va a ser otra víctima de esta estrategia de encubrimiento de la represión militar en Ayacucho. Una explicación de esta ansiedad es cómo se ejerce un control nacional desde el engaño (la asimilación a un destripador limeño) y la verdad cómo reconstrucción somática de la ciudad. El cuerpo se asimila a la propia ciudad a través del reparto de los miembros cortados por distintas zonas de la ciudad y parte de la investigación consistirá en descifrar el espacio concreto en que ha ocurrido la escena del crimen.

Uno de los elementos novelescos a considerar es la presentación de una connotación ideológico-histórica del territorio limeño ya que los acontecimientos se producen en los años noventa y tienen referencias directas o implícitas sobre procesos políticos. En este caso, el fujimorismo y su respuesta excesiva a los ataques de Sendero Luminoso. Al respecto, la ciudad se configura como un actor de la dinámica histórica en la que circulan los personajes y se revela como marco en que la criminalidad político-estatal tiene lugar. De hecho, los poderes siempre están centralizados en las capitales y desde ahí se generan las órdenes y los dictámenes por lo que el asunto del poder político atraviesa la novela. Eso sí, Elmore a través de dos personajes que actúan como investigadores hace recaer gran parte del interés narrativo en el efecto que sobre otros actores de condiciones mucho más limitadas tiene resultado este plan militar que es auxiliado indirectamente por la prensa amarillista. Al centro del poder político y criminal responde Elmore si bien con el fracaso de la investigación con una dosificación narrativa que otorga a mi modo de leer esta novela con los testimoniantes como sujetos de gran interés para el relato. Los testigos acaban desplazando la propia investigación como centro de la restitución de la verdad en el relato criminal en beneficio de una nueva historia que tiene que ver con los efectos de la violencia política en los sujetos anónimos de la metrópolis. Y aquí la agresividad es especialmente dolorosa en sus efectos.

En relación con la Lima descrita materialmente desde un aspecto físico, existen referencias al centro, a las plazas, a la avenida La Colmena, a la periferia y a Miraflores, en menor medida. Al respecto, junto a este carácter descriptivo de la ciudad, también Lima se prefigura como una ciudad productora de sentido, lo que se aprecia y evalúa por ejemplo en las búsquedas de Saldívar y especialmente en la obsesión de Walter Zárate por encontrar pistas concretas sobre el crimen. Así, la urbe se muestra por un 
lado física, con actores sociales específicos que contradicen la lógica anunciada de un serial killer televisivo, como el mismo Saldívar elucubra. El crimen y las entregas parciales de los cuerpos a través de los miembros desperdigados exhiben a víctimas específicas en la sociedad limeña segregadora, desde emolienteros, hampones y guardianes que van deshaciendo sus expectativas en medio de una ciudad y un país que empieza a sufrir los embates de una guerra cruenta y empecinada entre el Estado y los insurrectos de Ayacucho, tal como se revela finalmente en la conexión de los cuerpos con las víctimas a propósito de la lucha despiadada en aquella zona andina. Mientras que en la zona andino sureña los crímenes deberían ser anunciados de otro modo, en Lima son reescritos y reexaminados a la luz de la crónica roja y del folletín amarillista, es decir, como cuerpos trucidados. Lo que es enunciado es el desastre que sucede en la provincia sureña y que se replantea en la capital como estrategia de encubrimiento de un asesinato. La acumulación y el número son pistas que hablan de una escena que no se ha cumplido y en que los criminales permanecen ocultos. A la vez que trabajo de desciframiento que conjuga a personajes honrados en busca de la verdad, como exige la lógica del relato criminal, también hay un trabajo del novelista en indagar sobre el la percepción en que los varios sujetos que pueblan la novela experimentan como una heterogeneidad territorial. Menos gloriosa y monumental, la capital en sus varios trayectos y recorridos proporciona una imagen de barriada antes que la imagen burguesa del literario distrito de Miraflores, por ejemplo que es prácticamente invisible como motivador del relato.

En esta novela la ficción proclama los excesos de la represión estatal en la guerra declarada contra Sendero Luminoso ${ }^{12}$. Así se decidió enfrentar de manera más directa la relación entre política y ciudad en la construcción del relato negro reciente, pero se manejó la idea de que hay un grupo más reducido de textos en los que se representa a nivel de actor al periodista-investigador y el mismo texto se acerca a cierta representación de la crónica roja a través de la interacción entre la ciudad corrupta y el poder político velado:

En lo que iba del año, ya habrían ocurrido más de cuatro mil homicidios. Era el cálculo de Andrés, sin ningún valor estadístico y probablemente demasiado conservador. Masacres senderistas, matanzas del ejército, atracos a bancos, balaceras entre narcos, reyertas de cantinas, crímenes de pasión. Las páginas de los diarios chorreaban sangre. Signo de los tiempos: había colas de varias cuadras para entrar a ver un mamarracho en el que, según los afiches, las escenas de canibalismo eran reales. A los cronistas policiales no les faltaba material, la cuota de muertes aumentaba sin pausa. Ya no había espacio suficiente para dar cuenta de cada víctima y, en la mayoría de los casos, los datos eran intercambiables (176).

12 Se recuerda incluso que existen muchas narraciones, obras teatrales y poemas que dan cuenta de estos hechos y que desde la narrativa peruana se conoce como conflicto armado interno, guerra sucia o literatura de la violencia política. 
La ciudad latinoamericana deja sentir la sospecha respecto a la construcción de la nación que se transparenta en los restos que encuentran los personajes del autor peruano y que no hace más que originar víctimas o resistencias cuando, por ejemplo, los personajes principales muestren su incomodidad cuando "invaden" la periferia en busca de pistas, es lo que sucede con Saldívar cuando viaja a Comas a entrevistar testigos. Se toma en cuenta que esta percepción clasemediera de los actores contribuye indirectamente a sesgar y a victimizar a los sujetos anónimos que pueblan la metrópolis y que la recorren de modo humanitario ya que aquellos trayectos constituyen desplazamientos laborales en sectores divergentes de su territorio.

Finalmente, en el fracaso de la figura del detective o del investigador para restituir la verdad encuentra coherencia la idea de que la cercanía con el periodismo revela una concepción multigenérica del verosímil que infiltra el relato policial en su sentido de exclusividad ${ }^{13}$ y que va desde una crónica amarillista en tanto descriptora de los cuerpos hasta un reportaje que jamás podrá salir a la luz y o, en otro sentido, también la aproxima a una crónica urbana. Esta práctica textual híbrida funciona también respecto a las verdades a medias que se articulan como decepciones para los personajes y para nosotros los lectores.

A su vez, en relación a la figura heroica del relato criminal, el reemplazo del detective tradicional por la figura de un periodista que encara la investigación parece más consistente con la contingencia latinoamericana. En su articulación polémica, esta figura podría llevar más adecuadamente una investigación de estos nuevos investigadores fracasados tal como se presentó en la novela de Elmore ${ }^{14}$.

La trilogía narcoliteraria de Alejandro Páez Varela: la restitución de la dignidad en la frontera norte de México

Para el caso de una ciudad tan identificada por imaginarios de la violencia como Ciudad Juárez se ha optado por un narrador que trabaja de periodista como Alejandro Páez Varela. Este autor ha escrito una trilogía compuesta por Corazón de Kaláshnikov (2009), El reino de las moscas (2012) y Música para perros (2013) con puntos de contacto internos que revela la sordidez de la agresividad que enlaza la vida de vivos y de muertos en la frontera norte ${ }^{15}$.

13 Lo que de por sí es muy arbitrario ya que es muy difícil de expresar una forma purista del relato policial y con menos certezas en el relato latinoamericano de crimen.

14 Y que se observa en otras novelas de la época como en Perder es cuestión de método (1997) del colombiano Santiago Gamboa.

15 Al final de su tercer libro Música para perros (2013), el autor revela el plan inicial de su trilogía novelesca a través de una Nota explicativa que destaca por algunos datos aportados. En ese caso, el nombre del desencanto que según Páez Varela da un tono unificador a las novelas de la trilogía y la indicación de los años ficcionales que cubre la trilogía, desde los ochenta hasta principio de los noventa, con lo que remarca una distancia al menos aparente de la llamada Guerra reciente entre el Estado y los grupos criminales encabezada por el presidente Felipe Calderón, aunque consienta en localizar la contemporaneidad de los hechos al período de consolidación neoliberal en México: "Abrumado por la urgencia de contar, en 2006 inicié un proyecto de tres novelas entrecruzadas que tocaran temas 
Como obra genética de la trilogía, Corazón de Kaláshnikov, es en el primer texto en el que la mujer asume un lugar central ya que los hombres parecen ser subsidiarios a ellas, aunque ejerzan de victimarios. La primera novela y acaso la central de las tres está dividida en tres partes intituladas en dos ocasiones con el nombre de la mujer que tiene un protagonismo central dentro del texto y que es víctima o victimaria en un mundo en que la violencia agobia y asfixia. El primer episodio de la novela impacta por la arbitrariedad con que es asesinado el personaje Jessica en la sección del mismo nombre:

la bala entró por el ojo izquierdo de Jessica y salió por la nuca, seguida por un chorro de sangre y materia blanda; y las esquirlas del quemarropa se estrellaron un instante después sobre la ceja y una parte del párpado, pintándole pétalos de una flor que primero fue rosa por la carne viva y luego de las horas se hizo negra. Ella no tuvo tiempo de ver pasar su vida en un instante, como dicen que se deja ver, porque lloraba conmovida mientras seguía por la tele, en vivo, la dramática desaparición, búsqueda, muerte y hallazgo de tres niños en un pueblo de Texas poco conocido hasta antes de la tragedia (13-4).

La escena es absurda: un sicario extermina a Jessica, una vendedora de medias, cuando ella se lamenta por la muerte de unos niños que transmitía la televisión y muere por un error de identificación ya que las balas estaban destinadas a Flor (llamada en verdad Concepción Valles) la pupila del Club Paraguay, que ella había acogido en su departamento. Si bien Jessica es un personaje menor en esta trilogía, que el autor comience su relato con esta muerte determina nuestra conciencia de lectores respecto a la violencia absurda que cobra a cualquier cuerpo como objeto de un asesinato cruento. Ahora esa muerte permite sobrevivir a uno de los personajes centrales de las historias que es Concepción Valles, la mujer que ejerce de prostituta y que acompaña muchas de las historias que articulan el conjunto novelesco de Páez ${ }^{16}$. También allí transcurre una de las historias con protagonismo femenino más impactantes de la novela como es la breve pero intensa referencia a Juanita Quinteros, la dueña del Club Paraguay de Ciudad Juárez en la tercera sección de la primera novela denominada casi como homenaje "Juanita". El Club Paraguay es un locus importante dentro de la

importantes para mí: el amor y el desamor, la pasión y la venganza, el abandono y la gracia, etcétera. Antes, en la década de 1990, mi entonces mujer me urgió a que empezara a escribirlas sin impostar la voz. Eso dijo y no lo olvido. Así nacieron Corazón de Kaláshnikov (2009), El reino de las moscas (2012) y Música para perros (2013), que pueden ser leídas juntas y por separado, sin orden específico; no están numeradas porque no son lineales: es decir, no están colocadas de manera consecutiva o subsecuente en una línea imaginaria de tiempo. Aunque las novelas tienen total independencia una de la otra, están ligadas por varias vías: caminan sobre una misma geografía, tienen un discurso narrativo recurrente, y el lector podrá descubrir que algunos de los personajes cruzan fronteras para relacionarse en distintos escenarios. El tiempo imaginario en el que transcurren es la década de 1980 y hasta principios de 1990.Corazón de Kaláshnikov, El reino de las moscas y Música para perros, reunidas, tienen un nombre. Las propuse como Los libros del desencanto a mis primeros editores. Ahora ese nombre no tiene importancia; pero me permitió, a la hora de escribir, pensar en una misma atmósfera” (Páez Varela, Música para perros 90).

16 Definidamente en las novelas uno y tres del ciclo. 
novela ya que motiva el segundo viaje de Flor hacia Ciudad Juárez, además desde el ámbito foucaultiano del poder en su función del prostíbulo que aparece en la trilogía es el espacio heterotópico más visible de la novela ${ }^{17}$. Al Club van una gran cantidad de sujetos masculinos de Ciudad Juárez y eso incluye a los jefes criminales. Desde la lógica foucaultiana es un territorio excepcional ya que las relaciones humanas se dan de otro modo al interior de este Club nocturno como espacio de sexualidad heterogénea a la de la institución matrimonial Y es justamente una práctica sexual extraña la que causa el choque trágico entre una casi adolescente Flor Valles y el jefe criminal que la había abordado. En el territorio excepcional del prostíbulo quién dispensa el dinero y maneja a otros sujetos detenta una condición privilegiada para imponer castigos que es lo que sucede a propósito de esta acción.

En consecuencia, Juanita se presenta como la cifra doscientos cincuenta de las mujeres asesinadas y el problema para la policía estatal es que a consecuencia del número redondo se va a producir una noticia, sumado a ello, la víctima como dueña del prostíbulo era conocida por varios habitantes que eran clientes del Paraguay por lo que la muerte deja de ser anónima dentro de los habituales crímenes de la Ciudad fronteriza:

[Julián Cisneros] En condiciones normales, las mujeres asesinadas en la ciudad eran una bendición para cualquier jefe de departamento. Si estabas en Desapariciones y Secuestros, a donde llegaba la primera denuncia, esperabas a que apareciera muerta y hacías un oficio para enviarla a Homicidios. El de Homicidios hacía lo mismo: un oficio, y a la Fiscalía Especial. Y el de la Fiscalía Especial podría responder, si el asesinato no sumaba un número redondo -como en este caso-, que ya se tenían pistas y que la investigación estaba avanzada. Así se ganaba tiempo.

Los doscientos cincuenta, estaba convencido, planteaba más retos. Pensó en lo que llamaban "el limbo", una figura usada por sus antecesores: si alguien preguntaba por cierto asunto, simplemente se respondía que estaba "por ser turnado a la Fiscalía" aunque ya hubiera llegado y que "hasta entonces tendremos informes" y así se podía esperar a que bajara el agua, hasta que desapareciera de las portadas de El Diario de Ciudad Juárez.

Juanita Quintero era una mujer conocida, razonó. Y había muchos, incluso dentro de la policía, que estaban interesados en el curso que tomara la investigación, si es que la había. Además, era la 250 (93-4).

Para el oficial Julián Cisneros que representa a la oficialidad no corrupta pero tremendamente ineficiente y poco responsable, la víctima viene a ser un problema en su reciente designación como Jefe de Homicidios. Al inicio de esta sección, Juanita

17 Según Foucault las heterotopías son los espacios localizables y contrautópicos que posee todo tipo de organización social, pero que a la vez es una zona diferente al resto de los territorios. A propósito del prostíbulo, el filósofo francés habla de un "espacio de ilusión" (79). 
de 50 años ya es una desaparecida secuestrada del Club y se acaba de encontrar los restos de ella, apenas una uña que resistió los embates del ácido con que su cuerpo fue disuelto ${ }^{18}$ y la broma cruel del autor al entregarnos como vestigio absurdo los implantes de silicona que ella se colocó un par de años previos a su desaparición. Juanita apodada la Grandota en el Club protege a Flor Valles tras la agresión que esta comete con su primer cliente, un jefe criminal peligroso. A raíz de la agresión y de la protección que brindan para esconderla, se decide la muerte de Flor y la de Juanita así es como también la vendedora de medias que muere por error en vez de Flor. La dueña del prostíbulo es condenada por defender a la joven mestiza de diecinueve años que acaba de llegar de un pueblo del interior ${ }^{19}$. En ese sentido, Juanita Quintero como dueña del prostíbulo es un problema para varios ex clientes del Paraguay y como sujeto mujer cae dentro del determinismo que cierra el mundo criminal de Juárez que se ha ensañado sobre las mujeres transformándolas en un objeto de agresión sexual o en su radicalidad como objeto de violencia física. A propósito de la violencia, rescato una lectura que, desde otra perspectiva y sobre la violencia que se ejerce en la Frontera, la teórica tijuanense Sayak Valencia elabora al solicitar un cambio radical en la percepción de la violencia machista y cómo es presentada medialmente, a propósito que se "presupone que la condición de vulnerabilidad y violencia son inherentes al destino manifiesto de las mujeres” (174). Reflexiono que Páez Varela evita esta situación al darle un protagonismo a una mujer como Flor Valles en toda la trilogía e incluso al presentar a un personaje femenino como victimario en la segunda historia de su primera novela lo que significa no victimizarla a partir del género ni condicionarla desde un determinismo fatalista a pesar de su vulnerabilidad inicial. Se menciona esto porque la relación entre Frontera y sobre todo Ciudad Juárez apunta al femicidio de modo "naturalizado" tal como lo refiere Valencia.

Con relación a Juanita, una vez asesinada, para la policía no es más que un número molesto e incómodo no un sujeto que requiere de una comprensión. Con relación a esto, si Páez Varela cuenta la historia posterior de la dueña del Paraguay esto la dignifica y la extrae de la mera cifra en que el Estado ha atrapado a las víctimas de Juárez. Da la impresión que la resolución criminal encuentra la complicidad policial en ese truco llamado "limbo", ejercicio de la burocracia que difiere la indagación y la preocupación pública. Cuando se cuenta la historia de Juanita en la novela, en cambio accedemos a un tipo de información cualitativa y de gran densidad que nos revela el coraje y la dignidad de la patrona al saber que no podría impedir su propia ejecución y así salvar a la adolescente Flor. La historia de Juanita también revela en el implícito que ella se siente duplicada por aquella joven, ya que ambas han venido de pueblos

18 De un modo similar a lo que Sayak Valencia explica como la técnica de "pozole, que consiste en introducir los cuerpos de los sujetos a aniquilar en una especie de bidones llenos de ácido, cuya composición logra corroer los huesos e incluso eliminar los restos de los seres que se introducen en ellos" (133).

19 En su ejercicio de prostituta reciente, Flor Valles ha violentado la intocabilidad de los criminales de Juárez al golpear y robar a su primer cliente, un jefe criminal que va a querer lavar su honra con violencia extrema sobre ella. 
pequeños en busca de mejores oportunidades y se han visto atrapadas en Ciudad Juárez. Es lógico pensar que la patrona le concede una oportunidad a la joven en una suerte de espejo de su propia existencia en la urbe criminal, lo que se va a producir en la tercera novela cuando definitivamente Flor salde sus cuentas pendientes con Juárez y logre abandonar la ciudad:

A Juanita se la llevaron del Paraguay. Las chicas jamás olvidarán su rostro firme y su actitud: ya en la puerta la empujaron y ella se volteó y abofeteó con fuerza al que estaba detrás. Le gritó: “¡Hoy me muero, pendejo! Me tratas con dignidad, ¿oíste? Créeme: eso, la dignidad, eso es lo único que te va a importar cuando sepas que ya no vuelves, ¿entiendes, pendejo? ¿Entiendes lo que te digo?” (136) [...] Juanita duró tres días sin comer, atada en una casa de seguridad en Ciudad Juárez. Murió de sopetón: le dieron un tiro en la frente. Para su fortuna, tenía los ojos vendados y estaba dormida. Como la prensa reportó su desaparición, la metieron en un tambo de ácido para borrarla. Los encargados de hacer el trabajo esperaron, dando vueltas al líquido hasta que no quedara nada, hasta que desapareciera. Y sellaron el contenedor. Lo fueron a tirar a un terreno baldío a las afueras de la ciudad. Uno de sus captores comentó, mientras se retiraban: "las chichis de Juanita, ¿te acuerdas? ¡Qué chichis!" (139-140).

En la historia de Juanita nos enteramos que también ha sido víctima de una violación siendo adolescente en Juárez a la salida de su anterior trabajo en la maquiladora, así termina por ingresar al Club Paraguay para conseguir algún tipo de trabajo. Menciono que en Haesbaert ("El mito de la desterritorialización”) se plantea que la maquiladora equivale a una concepción del territorio de forma asimétrica. Es una empresa cuyos empleados precarizados son los verdaderamente desterritorializados respecto a los dueños de aquella $(15)^{20}$. En este sentido, la historia muestra un mundo similar al de Flor en tanto ambas provienen de pueblos pequeños de la sierra y aunque en la circularidad del destino de la mujer las dos parecen condenadas, el sacrificio de Juanita y la ayuda solidaria de la vendedora de medias Jessica lograrán darle una nueva oportunidad a Concepción Valles y su hija tal como se muestra en el desenlace de las tres novelas. Tanto en su secuestro como en su martirio Juanita defiende lo que ella denomina dignidad en sus últimos momentos de vida y como ironía cruel reaparece la referencia de sus captores a la anatomía injertada de ella y que va a conducir a la hipotética investigación y a reconocerla como una asesinada más de Ciudad Juárez. Es a través de ese injerto y de la uña como Juanita alcanza una reparación al menos como un nombre a pesar que la policía busque omitir su presencia como sujeto mujer victimizada, una más de la cruel nómina de la ciudad fronteriza.

20 Es la perspectiva económica a la que alude Haesbaert ("El mito de la desterritorialización”) para explicar las diferentes concepciones de la desterritorialización. 
En la segunda novela, El reino de las moscas, Ciudad Juárez sigue con un rol central como espacio de muerte, evoco la reflexión de Mbembe surgida de Fanon sobre la construcción de ciertos territorios en los que la excepción es la regla para la masacre. La explicación de esta situación de Juárez la podría rescatar mejor de Sayak Valencia al entender el proceso de las maquiladoras y de las practicas de violencia radical que ocurren allí se explican al comprender esta zona como un laboratorio del capitalismo al constituir la zona fronteriza de un país rico con un país pobre. Entre estos pueblos, pueblos y villorios pequeños donde algunos personajes tienen su origen y muchas veces migran a Juárez y allí son sometidos a actos de violencia trascendentes en su existencia, Zaragoza parece condenar a los personajes que se mueven de allí como los nacidos en las afueras de esta localidad, como Moisés y su novia Magdalena que son de "Distrito Bravo, Chihuahua" con una gran impronta de la religiosidad que afecta a sus familias en sus nombres y que establece una orientación semántica a veces irónica con sus destinos. El pueblo de Zaragoza se muestra como un territorio de condena y es descrito a veces como peor que la misma ciudad Juárez, lugar de agresión contra la mujer y que establece continuidad con la violencia de la ciudad central de la trilogía:

Ciudad Juárez le quedaba al poniente. Los separaban los algodonales, acequias ralas y una maquiladora pionera: la RCA Victor, que sólo empleaba a las juarenses porque una mujer de Zaragoza, en esos años, era peor que un indigente y, por lo tanto, tenía muy pocas opciones laborales, a saber: o era bailarina de uno de los puteros del Valle de Juárez o viajaba a diario a la ciudad para limpiar baños y tender camas [...] O bien se quedaba en casa a esperar a que uno de esos de la esquina, tejedores profesionales del tiempo muerto, se la robara y la llevara a unos cuartos de adobe y le diera hijos que después se juntarían en el quiosco a fumar mariguana, a beber cerveza y a presumirse los callos de la pizca del algodón (18).

La caracterización de la mujer de Zaragoza no deja lugar a dudas de este determinismo en que el género parece enclaustrarse en esta zona de la frontera norte mexicana, al menos medialmente, aunque Páez Varela logrará socavar esta imagen al darle un destino desconocido a Magdalena. Comento que la Frontera Norte responde a la teorización de Haesbaert ("Del mito de la desterritorialización”) para definir el territorio ya que a su base física es una zona de producción cultural y de intercambios que incluso tiene una amplia representación narrativa y teatral. Al respecto me quedo con un punto interpretativo agudamente comentado por Sayak Valencia en que ve a esta Frontera como una zona de intersección entre el Primer y el Tercer Mundo. Según esta teórica las fronteras de este tipo son la cuna para lo que ella denomina capitalismo gore (124), es decir, espacios en que el hiperconsumo ha fomentado estas prácticas de violencia radical que están relacionadas con los mercados internacionales y sus dinámicas. Retomo, el poblado de Zaragoza aparece caracterizado como tierra de 
un sujeto que es agraviado de forma permanente, donde la mujer ocupa uno de esos lugares de desmedro acompañada de los humildes que ni siquiera pueden optar al sueño y las expectativas de los migrantes que van a Estados Unidos. El determinismo y la precariedad caracterizan a estos sujetos que parecen condenados a vagar en estas zonas mexicanas. Aunque la presentación de esta zona lleva a una construcción de un determinismo fatalista, desde Haesbaert ("Del mito de la desterritorialización") se puede explicitar una vez más las posibilidades multiterritoriales que ofrece como posibilidad a los personajes de estos lugares, en este caso, los migrantes internos que buscan mejoras económicas en Ciudades donde circula el capital como Juárez. Lo que a propósito del brasileño se puede constatar es que las posibilidades de cambio son asimétricas respecto a los trayectos y desplazamientos laborales a los que estos sujetos tienen acceso, por ejemplo, Juanita llega a una maquiladora y termina en un prostíbulo, a lo más accede a ser patrona del mismo; Flor Valles llega directamente al Club nocturno; Magdalena puede ser una empleada en casa de los Labrada. La voz de aquellos está condicionada por lo que su cuerpo pueda producir sexualmente en los cabarets de la zona o directamente como empleadas de las maquiladoras. De hecho Juanita ha sido trabajadora de maquila antes de pasar a formar parte de un club nocturno en un ciclo que parece condicionar la existencia de todos los personajes y que Concepción Valles podrá romper merced al sacrificio de sus amigas y a su propia determinación para imponerse a una situación de menoscabo como trabajadora sexual de un poblado:

\begin{abstract}
¿Quién vivía en Zaragoza? Ni siquiera los migrantes, porque esos, después de intentar sin éxito el sueño americano, se pasaban un tiempo rondando Ciudad Juárez y encontraban las lomas más al poniente, en donde es posible armar un cuarto con cartón y palos [...] En Zaragoza vivían los de mayor pobreza. Vivían los despojados del Valle de Juárez, nietos de indios insumisos que todavía a principios del siglo XX cortaban cabelleras y andaban con su orgullo a caballo, pero que fueron abatidos por los ejércitos de Estados Unidos y México. ¿Quién vivía en Zaragoza? Personas en duelo permanente, que no aspiraban a cruzar a Texas porque no sabrían ganarse la vida allá, en donde, en teoría y sólo en teoría, no se necesita más que estar dispuesto a ser esclavo (18-9).
\end{abstract}

En El reino de las moscas se muestra - con la misma técnica de dividir en tres secciones la novela- fundamentalmente la historia de amor y de violencia del jefe criminal Liborio Labrada y de su esposa Ana y las víctimas y victimarios que los rodean como el ex comandante Cuco Ramírez y los jóvenes Magdalena y Moisés. Un comentario sobre el protagonismo de Liborio Labrada, a propósito de la reflexión de Sayak Valencia, Liborio constituiría un sujeto endriago tercermundista, es decir, una subjetividad capitalista que pone en escena practicas de violencia extrema para afirmar su individualismo y obtener dinero en estas zonas de laboratorio del capitalismo gore (92). En un aspecto importante de sus relatos, Páez Varela muestra distintos trayectos de huida 
de sus personajes ya sea como migrantes internos para mejorar su condición social o ya, caídos en desgracia, como Liborio tratando de escapar a una muerte segura por otros criminales y la justicia corrupta como en el caso del traidor comandante Cuco Ramírez un ex aliado. En tales aspectos se observa como los distintos personajes son puestos en distintos territorios lo que revela condiciones distintas a lo largo del relato, para el jefe Labrada, la seguridad de su casa puede metamorfosearse en un infierno, o una pieza en la que tortura a una víctima o los distintos refugios que lo acogen en su huida o la aceptación de Ciudad Juárez como su destino final si decide retornar a aquella. Aquí es el poder o la desigualdad en el acceso a ciertas zonas como diría Sack la que configura políticamente un territorio y las modificaciones que al interior de la novela muestren los lugares.

A la par que laboratorio novelesco del capitalismo gore, Páez Varela apela en más de una oportunidad a la estructura melodramática como posibilidad de salida de la violencia extrema que detalla. Así, el autor confía en los afectos y en las historias de amor más allá de la muerte y rescata en esa condición incluso a alguien como Liborio respecto al trato afectuoso que dispensa a Ana su mujer. Eso sí, Liborio ha sido alguien muy poderoso como se observa cuando el joven Moisés es sometido a tortura por el jefe criminal hasta su muerte por haber intentado robarle (44-5). El joven es asesinado como un castigo en un plan organizado en realidad por la novia del muchacho y sirvienta de los Labrada Magdalena, que sobrevive milagrosamente al aparente determinismo del resto de los personajes. Parte del conflicto que afecta incluso a los personajes criminales se muestra en la novela cuando Liborio experimenta un malestar al asesinar directamente a sus víctimas y conservar en su memoria el rostro desencajado de ellas. "Los rostros te dejan algo y no los puedes olvidar, porque todos los muertos tienen una misma sonrisa. Es un 'ya te chingaste, puto. Yo ya me fui'. Y tienen razón” (57). El cuerpo es un síntoma que es mostrado explícitamente en la narrativa del norte mexicano. Así como en la muerte por inanición de Moisés, Liborio destruye de hambre y sed el cuerpo del muchacho, el mismo criminal sabe que las miradas de los cuerpos destruidos lo amenazan con esa sentencia que ya como espectro futuro el mismo Liborio le dedica a Cuco Ramírez "Estás pagando por tus pecados" (9). El rostro de los vivos transformados en cadáveres recuerdan a Liborio que las muertes no serán gratuitas y que aquellos sujetos terminarán por encadenarlo en el círculo de violencia con que él se ha apoderado de Ciudad Juárez. Aquella grotesca mirada deformada de quien es asesinado establece el precio a pagar y la condena futura del jefe criminal a través del asesinato cruento de su esposa Ana. El precio de Liborio y el de otros personajes como él es el ajusticiamiento de las personas cercanas o como en el caso terrible del ex comandante Cuco Ramírez cuando ya anciano, caso extraño para un sujeto que ha vivido en medio de la traición y la violencia, experimenta la horrible muerte de sus nietas despedazada uno por sus perros y muerta la otra por intoxicación de monóxido de carbono. El precio de una discutible justicia alcanza a alguien incluso para cuando la edad parece dejarlo libre de la crueldad que él mismo 
desató en otros tiempos. En este caso es sentenciado por los espectros de los dos hermanos Labrada que vuelven de ultratumba para recordarle que su deuda se ha cobrado con ensañamiento.

En Música para perros, Páez Varela da cierre a su trilogía contando la historia de un muchacho sicario que resulta ser sorpresivamente identificado al final como uno de los hermanos perdidos de Concepción "Flor" Valles (y un enamorado platónicoincestuoso de ella sin saberlo) y cerrando el círculo de la ex joven del Club Paraguay, su esposo Graciano y el presunto padre de la mujer llamado José Crisanto en una salida narrativa optimista. Así, finalmente se reencuentran Concepción Valles, su hija Flor y el anciano José Crisanto para tratar de reparar y salir de ese círculo de victimización que afecta a todos los personajes mencionados. Como parte del eje argumental de esta novela mientras Graciano el esposo dependiente y ex chófer abandonado cae bajo la pistola de Liborio, el anónimo muchacho hermano de Concepción Valles que si bien vive y trabaja a las órdenes de Labrada como sicario no oficial pero, a la vez, clausura también el circuito de la muerte violenta al fallecer destruido por el cáncer que asimismo se había llevado en otra época a su madre. Morir de una enfermedad terminal en Ciudad Juárez parece constituir el cierre de la violencia extrema que ha mostrado el universo narrativo de Páez Varela.

Como objetivo, Páez restituye la dignidad a sus personajes al establecer una red de elementos que humanizan el espacio del desastre. Acaso en esta opción del autor puedo hacerla confluir con un concepto de Haesbaert ("Del mito de la desterritorialización") sobre la apropiación simbólica de los territorios en vez de la material que es quién detenta el poder en las zonas específicas. Existe una suerte de creación simbólica de lugares que en la novela interpreto como esta posibilidad de ruptura con la pura posesión física y dispensa de la violencia radicalizada que se exhibe en la zona norte de México como la cocina en que se juntan la mujer que acogió al muchacho sicario y lo protege como una madre. Para ello, se detecta una serie de símbolos inexplicables en el universo narrativo de la violencia explícita como el extravagante león del zoológico privado de Labrada que libera Graciano antes de caer asesinado, la flauta que toca el muchacho y que desespera a Liborio. Este proceso lo haría extensivo a la aparición de una serie de espectros que otorgan una nueva existencia a los víctimas-victimarios como la reaparición de Juanita Quintero en el Club Paraguay, la de Liborio Labrada y su hermano a través del reencuentro de los afectos y pasiones más allá de este mundo viniendo a hablarle a Cuco Ramírez. Finalmente en esta restitución de dignidad, se destaca las relaciones maternales y filiales que se establecen entre varios personajes agobiados por los hechos de sangre pero que al calor de su historia familiar y de sus afectos reencuentran la historia perdida de su propia restitución de dignidad y esto afecta a distintos sujetos de la novela. Paradigmático es el segundo viaje de "Flor" Valles a Ciudad Juárez en el que ella destruye su apacible vida familiar pueblerina porque tiene cosas que resolver con el pasado en que fue salvada por las mujeres del Club Paraguay a costa del asesinato de Jessica y Juanita. Este segundo viaje desde 
una perspectiva geográfica es muy diverso del anterior porque ella a diferencia de la muchacha que acometió imprudentemente el viaje anterior va a un territorio material que es distinto para ella, va con un objetivo en que determinará cerrar su circuito de afectos con el mundo heterotópico del Club Paraguay, del que ahora se desencantará. Como sujeto, Flor ha cambiado y el territorio al que ella accederá cambia con la metamorfosis de ella, en ese sentido descubre que sus expectativas son frustradas y por eso podrá retornar a su poblado para rehacer su existencia con su hija y con la aparición de una figura paterna que la acogerá y que da el cierre a este universo de violencia que se acaba.

En el capítulo "La olla exprés" Concepción Valles le habla a alguien no identificado que parece ser Crisanto de lo que significa Ciudad Juárez como espacio:

Juárez es un hoyo negro. A Juárez no se va a aprender porque si aprendes allí, ya te llevó la chingada. A Juárez se va a luchar, a sacar los dientes. O te hundes. O te hunden entre todos.

Mire: no es que la gente sea mala. Tampoco que el aire sea malo. Es tanta mierda. A Ciudad Juárez lo pudren los políticos porque Juárez, se lo digo de verdad, Juárez es noble. Sí, sí, como dice Juan Gabriel: Juárez es noble. Los que no son nobles son los pinches políticos. Puta bola de vividores. Puta bola de corruptos. La inocencia y la honestidad, en ese mundo podrido, son como la virginidad en una central de camiones, de madrugada: porque está allí, todos creen que se merecen mancharla. Porque está allí, todos sienten que es gratis. Porque está allí no tiene dueño y porque está allí, es de todos.

Así es este mundo. Y qué se le va a hacer (Música para perros 45).

En la opinión de "Flor" Valles es la propia estructuración del Estado la que mancha a Ciudad Juárez y la corrompe. Lo que aparece a veces como una opinión masiva sobre la configuración estatal de la violencia es restituida por el autor desde el ángulo de la mirada no-oficial que incluye sacar a las víctimas y a los propios victimarios de la elaboración como cifra de la criminalidad. Así esta trilogía del desencanto encuentra un paralelo en la protesta de los periodistas sobre la guerra contra el narcotráfico que motiva los testimonios de crónicas diversas a cargo de Páez Varela y en donde comenta desde el ángulo periodístico el fracaso de la política de Calderón respecto a la criminalidad en el norte mexicano. Este aspecto de denuncia sobre la guerra fracasada con la criminalidad del gobierno de Felipe Calderón es una lectura muy legítima de la trilogía a pesar de que el autor la niegue en la Nota aclaratoria. Pero en el libro periodístico de 2009 que él coordinó la alusión a este proceso es explícita: "En Ciudad Juárez, por la negligencia del gobierno, se ha arraigado el torbellino de la bestialidad, la antítesis de las ideas del humanismo y el progreso. Y todo ello debe ser contado" (16). Al menos, es una lectura posible y muy legítima.

En otro aspecto, incluso los criminales tienen lugar para la redención en el texto y la culpabilidad es más dura con Refugio "Cuco" Ramírez ex comandante de la policía 
y su lugarteniente el Zurdo y con los cómplices involuntarios como el jefe de homicidios Julián Cisneros. Sacar del olvido y la desmemoria a las víctimas de la violencia es otorgarles una historia que repare esa indignidad en que mueren y son escamoteados a través de un número como la cifra " 250 " en que Juanita Quintero desaparece en los archivos policiales, ella que seguramente ha sido amiga de políticos y policías es olvidada como un problema público junto al resto de las mujeres asesinadas de Juárez. Y por eso, Páez Varela da un lugar privilegiado a las mujeres en la construcción de las historias, ellas que han sido mancilladas, violadas e injuriadas son reparadas incluso cuando puedan haber cometido errores como el de Magdalena cuando intenta robar a sus patrones Labrada. E incluso los mismos criminales como el terrible Liborio Labrada y el crepuscular hermano anónimo de "Flor" encuentran un espacio de redención a través del afecto dispensado tanto por la pasión respecto a Ana como por el amor materno que el muchacho casi un salvaje dispensa a la anciana criada de los Labrada y que traduce cuando pronuncia de adulto un tibio "mamá". Y esta palabra también se puede reinterpretar desde la lógica de un espacio privado que el muchacho en su rol público de aprendiz de sicario ha podido rehabilitar para su formación como sujeto. Es decir, frente al determinismo que provoca el uso machista de la violencia extrema, el joven apuesta en su mundo privado por la relación con esta anciana y por aislarse tocando una flauta. En un universo que promueve el desencanto y la explicitud de la crueldad Páez Varela se juega por una reconstrucción que ya poco tiene que ver con la resolución de crímenes y por la intervención del Estado en la reparación sino por una opción casi religioso-ética en que los personajes alcanzan incluso más allá de la muerte su redención persona. Ya sea a través de la amistad y solidaridad de las víctimas como de la pasión maternal y amorosa que ellos pueden obtener si cuentan con la actitud subjetiva para desarrollar tales afectos. En un modo no oficial de conjurar y romper el determinismo que instala la violencia en Ciudad Juárez y al que según la versión del autor colaboran de modo culpable las propias autoridades y organizaciones estatales y que contribuyen a la consolidación del imaginario de la ciudad como territorio de la muerte. Me permito una última reflexión a propósito del pensamiento sobre Tijuana como capital gore que expone Sayak Valencia. Para la autora Tijuana pone en ejecución una episteme de la violencia porque dispone de los cuerpos como una mercadería truculenta sobre la que ejerce una violencia extrema en que la vida tiene un valor de intercambio transnacional (137). Tijuana es una ciudad fronteriza como Ciudad Juárez que también ha acuñado un imaginario como territorio de la muerte a propósito de los femicidios y de la explotación de las maquiladoras, en este sentido, la reflexión también la encuentro valida para la urbe de Páez Varela. Dentro, eso sí, del universo narrativo que congregan las tres novelas, el autor mexicano ha provisto a sus personajes segregados por género y por desigualdad económica una salida de ese círculo de violencia que coincide con la posibilidad de efectuar trayectos materiales afuera de la ciudad. Así como el dinero y la violencia extrema integran parte de este circuito que determina las condiciones de existencia de los sujetos, el uso 
tanto simbólico de creación de espacios íntimos como la migrancia de esta ciudad de oportunidades engañosas - al menos para aquellos personajes- otorgan la posibilidad de abandonar el territorio de vivir una existencia precaria como hipotéticas víctimas.

\section{Conclusión}

Un registro de textos latinoamericanos de décadas recientes permite la observación de la criminalidad y de víctimas en territorios bien diferentes entre sí aunque comparten el hecho de funcionar como lugares de muerte o espacios donde se puede ser asesinado sin responsabilidad como dice Mbembe. Desde una Bogotá multiterritorial a una Ciudad Juárez asediada por la impunidad, la novela en tiempos recientes construye una reflexión sobre la víctima localizada en contextos narrativos tanto materiales como simbólicos que aluden a hechos referenciales: una masacre real en Satanás de Mendoza, un asesinato hipotético de la guerra sucia en el conflicto interno en Elmore y un conjunto de muertes arbitrarias como aquellos femicidios reales en la construcción de la trilogía del desencanto de Páez Varela. A partir de novelas que juegan libremente con el tema de la criminalidad, la intención que se puede extraer de ellas indaga en los males mayores de la nación-Estado latinoamericana. Si bien el conjunto de la verdad es subvertido y sobrepasado por las prácticas del poder que silencia y perturba el origen de los crímenes, en su estructura comunicativa cada novela nos interpela a reconstruir los fundamentos de una verdad que la historia oficial se niega a referir. En los tres casos las víctimas fundamentales son los personajes subalternos básicos para seguir la narración: María de Mendoza, los jóvenes reclutas infiltrados y los trabajadores de Elmore y las mujeres de Páez Varela. Aunque la nueva historia nacional relatada en estas novelas esté fracturada en parte por los homicidios, sirve para dar cuenta de los acontecimientos que han constituido a estos personajes y que están fraguados desde territorios específicos. Una Bogotá que se muestra segregadora y asfixiante, una Lima que funciona como un enigma alrededor de un crimen monstruoso, una Ciudad Juárez que acoge a personajes que sobreviven de modo precario hasta que son asesinados. Los tres territorios cuentan historias de poder desde el lugar de la víctima y de la derrota de quien sufrirá las consecuencias de estar encadenado a un circuito de violencia que busca ser deshecho de la situación comunicativa en que se nos interpela a los lectores. Eso sí, Páez Varela intenta otras salidas para algunos de sus personajes basado en la solidaridad con las víctimas. Se puede afirmar que la agresividad con que se muestra el proceso de la violencia en Latinoamérica coincide en la asimetría social con que los afectados e investigadores son exhibidos al interior de cada novela. Y ese registro desigual se muestra a través de la multiterritorialidad con que las zonas latinoamericanas son dispuestas para que los personajes interactúen de modo desigual. Esto es especialmente decisivo en las migrancias forzadas de los personajes a causa de situaciones económicas adversas y 
de los espacios laborales que ellos deben asumir cotidianamente. Frente a eso, quienes detentan el poder organizan su propia territorialidad y son capaces de activar sus redes de tránsito de modo voluntario, aunque pueden modificar su estatus si caen en desgracia como es el caso del jefe criminal Liborio Labrada que pasa de victimario a víctima en la ficción de Páez Varela.

\section{Referencias}

Atehortúa Cruz, Adolfo León. "Decisiones y narcos. Discusiones recientes en torno a los hechos del palacio de justicia”. Revista Análisis Político 71 (2011): 91-108. www.revistas.unal.edu.co/index.php/anpol/article/view/44238/45531. Fecha de ingreso: 12 enero de 2014. Sitio web.

Calvino, Italo. "La ciudad-novela en Balzac". Por qué leer los clásicos. Trad. Aurora Bernárdez. Barcelona: Tusquets, 1993. 112-115. Medio impreso.

Elmore, Peter. Enigma de los cuerpos. Lima: Peisa, 1995. Medio impreso.

Foucault, Michel. "Espacios diferentes". El cuerpo utópico. Las heterotopías. Buenos Aires: Nueva visión, 2010. 63-81. Medio impreso.

Haesbaert, Rogério. "Del mito de la desterritorialización a la multiterritorialidad". Revista Cultura y representaciones sociales (2013): 9-42. Universidad Nacional Autónoma de México. www.journals.unam.mx/index.php/crs/article/ view/41590/37807. Fecha de ingreso: 20 de enero de 2014. Sitio web.

---. "Territórios, in-segurança e risco em tempos de contencão territorial”. iner.udea. edu.co/grupos/GET/Seminario_Geografia_Perla_Zusman/12-Haesbaert.pdf. Fecha de ingreso: 5 de febrero de 2014. Sitio web.

---. "Viviendo en el límite: los dilemas del hibridismo y de la multi/transterritorialidad”. Geografías culturales: aproximaciones, intersecciones y desafíos. Coord. Perla Zusman, Hortensia Castro, Susana B. Adamo. Buenos Aires: Editorial de la Facultad de Filosofía y Letras Universidad de Buenos Aires, 2011. 49-76. Medio impreso.

Mbembe, Aquille. Necropolítica. Santa Cruz de Tenerife: Melusina, 2011. Medio impreso. Mendoza, Mario. Satanás. Bogotá: Seix Barral, 2003. Medio impreso.

Olaya Molina, Edwin. Pozzetto. Tras las huellas de Campo Elías Delgado. Bogotá: Librería Jurídica Sánchez, 2007. Medio impreso.

Páez Varela, Alejandro. Corazón de Kaláshnikov. El amor en los tiempos del narco. México: Planeta, 2009. Medio impreso.

---. El reino de las moscas. México: Alfaguara, 2012. Medio impreso.

---. Música para perros. México: Alfaguara, 2013. Medio impreso.

--- Coord. La guerra por Juárez. El sangriento corazón de la tragedia nacional. México: Planeta, 2009. Medio impreso.

Prado Biezma, F.J. Cómo se analiza una novela. Madrid: Alhambra, 1984. Medio impreso. 
Valencia, Sayak. Capitalismo Gore. Santa Cruz de Tenerife: Melusina, 2010. Medio impreso.

Todorov, Tzvetan. Introducción. Lo verosímil. Comunicaciones 11. Trad. Beatriz Dorriots. Buenos Aires: Tiempo contemporáneo, 1970. 11-15. Medio impreso.

Recibido: 09 abril 2014 Aceptado: 19 agosto 2015 